\title{
Meningkatkan kinerja usaha kecil menengah dengan pendekatan value engineering
}

\author{
M. Muslimin Ilham ${ }^{1)}$, Ferry Suzantho' ${ }^{2)}$, Surahmad ${ }^{3)}$, Fuad Achmadi ${ }^{4)}$ \\ ${ }^{1}$ Program Studi Teknik Mesin, Fakultas Teknik, Universitas nusantara PGRI Kediri \\ ${ }^{2,3,4}$ Program Studi Magister Teknik Industri, Institut Teknologi Adhitama Surabaya \\ E-mail: ${ }^{1}$ im.muslimin@unpkediri.ac.id
}

\begin{abstract}
Abstrak
Saat ini, penggunaan value engineering sudah dilakukan diberbagai bidang usaha. Tidak hanya perusahaan yang besar, tetapi UKM yang berada di daerah juga sudah mulai mengenal metode pengelolaan usaha dengan value engineering. Penelitian ini berupaya menjawab masalah tentang bagaimana cara agar UKM dapat meningkatkan kinerjanya berdasarkan pendekatan Valu e Engineering. Penelitian ini merupakan penelitian kualitatif. Dari kegiatan penelitian, diperoleh simpulan sebagai berikut. (1) Penerapan metode Rekayasa Nilai pada UKM Pagar Besi dapat menyelesaikan solusi yang lebih baik dalam rangka peningkatan kinerja perusahaan. (2) Berdasarkan alternative kombinasi metode kerja yang dibuat maka, alternatif penerapan rekayasa nilai yang terpilih. Karena penerapan rekayasa nilai ini mempunyai keuntungan-keuntungan antara lain: (a) Proses produksi cepat, (b) Pengerjaan rapi, (c) Harga jual lebih tinggi. Sedangkan spesifikasi teknik yang dimiliki oleh alternatif Value Engineering yang akan dijalankan adalah sebagai berikut : (a) Proses kerjanya tidak membutuhkan waktu lama untuk pembuatan 1 unit pagar besi minimalis. Untuk ukuran $8 \mathrm{~m} 2$ hanya dibutuhkan waktu 2 hari. (b) Mutu dan kwalitas yang disyaratkan mempunyai bentuk yang sempurna dan tidak cacat. (c) Sambungan bagian pengelasan tidak mudah patah oleh benturan/pukulan. (3) Pengurangan biaya dapat dilakukan pada metode Value Engineering, karena perubahan metode baru pada proses produksi pembuatan pagar besi minimalis mempengaruhi pengurangan biaya-biaya tenaga kerja. Pengurangan biaya tersebut akan mempengaruhi naiknya peningkatan performance yang lebih tinggi dari produk, sehingga nilai dari produk menjadi naik, maka mempengaruhi harga jual menjadi tinggi.
\end{abstract}

Kata Kunci: Value Engginering, SDM, UKM, Proses Produksi, Modal.

Abstract

Currently, the use of value engineering has been done in various business fields. Not only large companies, but SMEs in the region have also started to recognize the method of business management with value engineering. This research attempts to solve the problem of how SMEs can improve their performance based on Value Engineering approach. This research is a qualitative research. From the research activities, obtained the following conclusions. (1) Application of Value Engineering method on SMEs can complete better solution in order to improve company performance. (2) Based on the alternative combination of work methods created then, alternative application of value engineering selected. Because the application of value engineering has advantages such as: (a) Rapid production process, (b) Neat workmanship, (c) Selling price is higher. While the technical specifications owned by Value Engineering alternatives that will be run are as follows: (a) The process does not work long time to manufacture 1 unit of minimalist metal fence. For the size of $8 m 2$ it only takes 2 days. (b) The quality and quality required have a perfect shape and

D iterima 24 M aret 2018; Revisi akhir 5 M ei 2018; D iterbitkan 15 Juni 2018 
are not defective. (c) The welding joints are not easily broken by impact / blow. (3) Cost reduction can be done on Value Engineering method, because the change of new method in production process of minimizing iron fence affecting the reduction of labor cost. The reduction of these costs will affect the increase in the higher performance of the product, so the value of the product to rise, then affect the selling price to be high.

Keywords: Value Enginering, human resources, SMEs, Production Process, Capital

\section{PENDAHULUAN}

Tuntutan zaman dengan berbagai kemoderan teknologi telah membawa perubahan cepat yang menyangkut berbagai kebutuhan manusia. Perubahanperubahan itu tidak saja menyangkut aspek perubahan dasar (dalam suatu produk barang/jasa), tapi lebih kepada keinginan-keinginan konsumen yang menuntut inovasi nilai-nilai yang dapat memberikan kepuasan. Berhasil tidaknya perusahaan untuk mempertahankan dan memperluas pangsa pasarnya ditentukan oleh perusahaan itu sendiri, dalam memahami dan menyediakan kebutuhan, keinginan serta harapan para pelanggan.

Masalah kualitas dan kelancaran produksi merupakan bagian penting dan perlu mendapat perhatian serius bagi setiap perusahaan. Apalagi kondisi saat ini semakin memberikan kesempatan lebih kepada pelanggan untuk memilih. Sehingga kemampuan untuk lebih memahami pelanggan dalam keputusan membeli/menggunakan suatu produk/jasa harus diperhatikan.

Kualitas industri menjadi salah satu faktor yang bisa mempengaruhi kepuasan pelanggan. Kualitas ini pada akhirnya dapat memberikan beberapa manfaat, diantaranya terjalin hubungan yang harmonis antara produsen dengan konsumen, memberikan dasar yang baik guna menumbuhkan loyalitas pelanggan dan membentuk suatu rekomendasi dari mulut ke mulut yang menguntungkan bagi industri tesebut.

Namun kualitas ini bukanlah berdasarkan sudut pandang atau persepsi pihak industri, melainkan berdasarkan sudut pandang atau persepsi pelanggan. Karena pelanggan yang mengkonsumsi produk perusahaan tersebut. Persepsi pelanggan terhadap kualitas produk merupakan penelitian menyeluruh atas keunggulan suatu produk. Sehingga perusahaan harus pandai-pandai untuk mengatur keuangannya tanpa harus mengecewakan konsumen.

Dewasa ini dalam dunia perindustrian sudah tidak asing lagi dengan istilah value engineering (VE). value engineering (VE) didefinisikan sebagai suatu teknik manajemen yang telah terbukti berhasil, menggunakan pendekatan yang sistematis untuk mencari keseimbangan biaya/fungsi, reliabilitas dan performance dari produk barang. Sehingga para penyedia jasa tidak perlu takut mengecewakan pelanggan namun tetap mendapatkan keuntungan yang maksimal[1].

Rekayasa nilai (VE) didefinisikan sebagai suatu usaha yang dilakukan secara sistematik dan terorganisir untuk melakukan analisis terhadap fungsi sistem, produk, jasa dengan maksud untuk mencapai atau mengadakan fungsi yang esensial dengan life cycle cost yang terendah dan konsisten dengan kinerja, keandalan, kualitas dan keamanan yang disyaratkan. Seperti yang telah disampaikan di atas berapa istilah lainnya sering digunakan untuk menyatakan value engineering. SAVE International (The Society of American Value Engineers International) menggunakan istilah yang lebih luas yaitu metodologi nilai atau value methodology yang juga bermakna sama[2]. 
Rekayasa nilai (VE) mencari alternatif terhadap desain yang original yang dapat secara efektif meningkatkan nilai (value) atau mengurangi biaya proyek atau produk. Alternatif-alternatif dapat dikembangkan dengan mengajukan pertanyaan yang mendasar sebagai berikut, "Apa lagi yang dapat melaksanakan fungsi yang esensial, dan berapa biayanya?"

VE merupakan suatu studi yang dilakukan oleh sebuah tim yang independen dan multidisiplin beranggotakan para ahli. Proses VE, yang biasa disebut dengan Job Plan, meliputi sejumlah aktivitas yang dilakukan secara berurutan. Studi VE meliputi suatu penelitian VE. Selama penelitian VE, tim mempelajari latar belakang proyek, mendefinisikan dan mengklasifikasikan fungsi-fungsi produk, mengidentifikasi pendekatan-pendekatan kreatif untuk menghasilkan fungsi-fungsi tersebut, dan kemudian mengevaluasi, mengembangkan dan mempresentasikan proposal-proposal VE kepada para pengambil keputusan kunci. Pemusatan perhatian kepada fungsi-fungsi yang harus dilaksanakan suatu proyek, produk, atau proses inilah yang membedakan VE terhadap pendekatan-pendekatan perbaikan kualitas atau penghematan biaya lainnya.

Dari uraian di atas, penelitian ini bertujuan untuk menghitung Value Enngineering untuk meningkatkan kinerja Usaha Kecil Menengah. Penelitian ini hanya berfokus pada jalannya produktifitas pagar besi minimalis pada salah satu perusahaan Bengkel las di daerah Tulung Agung. Diharapkan dengan adanya penelitian ini, dapat memberikan masukan pada pihak manajemen sebagai bahan pertimbangan dalam melakukan upaya peningkatan kinerja kualitas perusahaan.

\section{METODE PENELITIAN}

Penilitian ini menggunakan metode deskriptif kualitatif. Metode kualitatif adalah prosedur penelitian yang menghasilkan data deskriptif berupa kata-kata tertulis atau lisan dari orang-orang dan perilaku yang dapat diamati[3]. Dengan demikian, penelitian kualitatif bersifat deskriftif, yaitu datanya berupa kata-kata. Adapun flowchart penelitian ini adalah sebagai berikut:

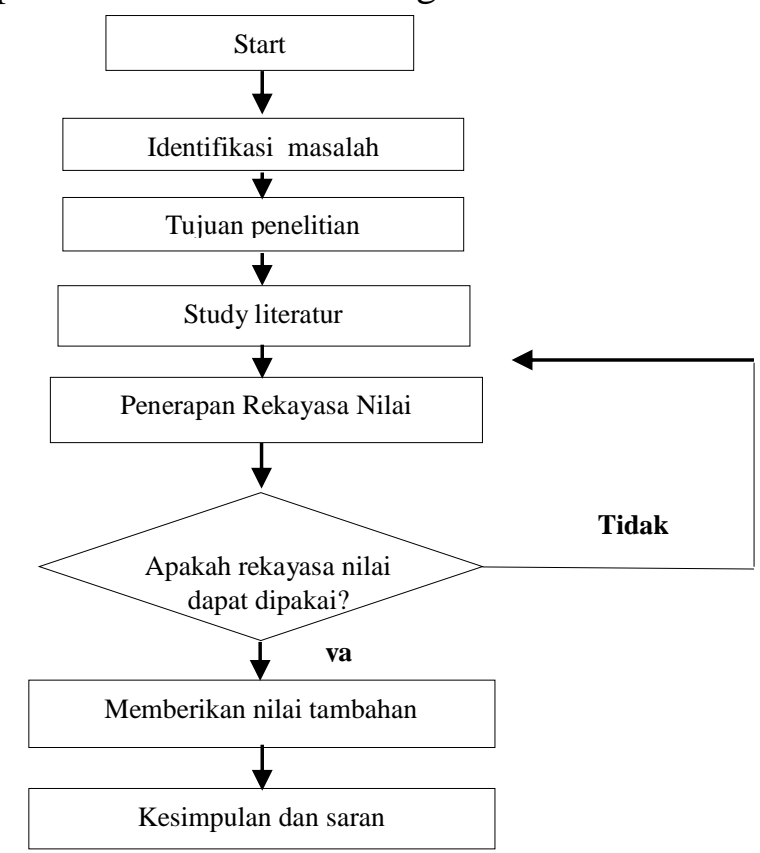

Gambar 2. Flowchart penelitian 
Tahap-tahap yang digunakan dalam metode Rekayasa Nilai meliputi [4] :

a. Tahap informasi, Merupakan tahapan untuk mengumpulkan informasi yang berkaitan dengan perancangan cara peningkatan kinerja UKM. Pada tahapan ini dilakukan dengan cara wawancara dengan narasumber dan observasi secara langsung. Informasi ini harus didapatkan sebanyak-banyaknya yang berhubungan dengan pokok bahasan dengan tujuan untuk memahami permasalahan yang dihadapi. Teknik observasi atau pengamatan dilakukan oleh si peneliti dengan melihat dan menghayati perilaku berbahasa di dalam suatu peristiwa tutur[5].

b. Tahap spekulasi, Dalam tahap ini dimunculkan alternatif-alternatif tandingan dari kinerja awal yang telah dilaksanakan sebelumnya. Caranya adalah dengan membuat suatu daftar desain alternatif yang didapat dari pemikiran kreatif tanpa dibatasi aturan atau pertimbangan-pertimbangan tertentu

c. Tahap analisa, tujuannya adalah untuk melakukan evaluasi terhadap alternatifalternatif yang dihasilkan pada tahap kreatif. analisa ini dilaksanakan untuk menentukan alternatif-alternatif yang dihasilkan pada tahap kreatif. Analisa ini dilaksanakan untuk menentukan alternatif terbaik di antara yang ada, yang memberikan potensi terbesar untuk meningkatkan kinerja.

d. Tahap pengembangan, tujuannya adalah memberikan saran terakhir secara tertulis terhadap alternatif yang dipilih. Selain itu, pada tahap ini dilakukan penyempurnaan yang menyeluruh terhadap alternatif yang dipilih. Pertanyaan kunci pada tahap pengembangan ini adalah " Apakah alternatif yang dipilih sudah memenuhi segala persyaratan ?". Pada fase ini memberikan pilihan yang terbaik dari beberapa alternatif yang akan dikerjakan

e. Tahap penyajian, tujuannya adalah melaksanakan apa yang sudah dibicarakan pada tahapan sebelumnya. Diterima atau ditolaknya alternatif yang diajukan sangat tergantung pada persiapan dalam pelaporan ini. Dalam melakukan laporan tidak perlu bertele-tele tetapi digunakan hal-hal yang bersifat spesifik, dan sebaiknya dilakukan laporan lisan langsung diperoleh dari pemilik perusahaan.

f. Tahap implementasi, tahap ini adalah untuk untuk mengetahui secara nyata apakah kinerja yang dihasilkan setelah melalui proses rekayasa nilai memberikan performan yang lebih baik dan dapat meningkatkan kinerja yang lama. Peningkatan kinerja untuk UKM ini diharapkan akan memberikan suatu perubahan terhadap tingkat kesejahteraan pemilik UKM. Penerapan Rekayasa Nilai akan memberikan manfaat yang besar terhadap para UKM, dalam meningkatkan kinerjanya.

\section{HASIL DAN PEMBAHASAN}

a. Tahap Informasi

Proses pengerjaannya pada bengkel las ini masih dilakukan secara manual manual. Beberapa karyawan yang mengerjakan proses tersebut kurang memiliki keahlian yang memadai. Pengeluaran yang dikeluarkan selama satu bulan adalah sebagai berikut:

1) Biaya Material $(\mathrm{Cm})$

Biaya material langsung yang harus dikeluarkan adalah sebagai berikut:

Besi 1 Rp. 60.000,-/lonjor $(6 \mathrm{~m}) \times 25$ lonjor/bulan = Rp. 1.500.000,-

Besi 2 Rp. 40.000,-/lonjor $(6 \mathrm{~m})$ x 234 lonjor/bulan = Rp. 9.360.000,- 
Cat 1 Rp.45.000,-/kaleng x 12,5 kaleng/bulan

Cat 2 Rp. 20.000,-/kaleng x 10 kaleng/bulan

Listrik = Rp. 250,000,-

Total biaya material langsung tiap bulan = Rp. 11.872.500,-

2) Biaya Tenaga Kerja (CI)

Jumlah tenaga kerja 9 orang, terdiri dari : 4 bagian Pengelasan, 5 bagian finishing

Pengelasan $=$ Rp.45000,-/hari $\times 25$ hari $\times 4$ orang $=$ Rp.4.500.000,-

Finishing $=$ Rp.27.500,-/hari $\times 25$ hari $\times 5$ orang

Konsumsi karyawan $=9 \times$ Rp. $7500 \times 25$ hari

Total biaya tenaga kerja tiap bulan

Jumlah produksi pagar tiap bulan : 100m2.

Harga pagar tiap m2 : Rp. 400.000

Pendapatan kotor tiap bulan $=(100 \%-0,1 \%) \times 100 \times$ Rp. $400.000=$ Rp. 39.960 .000

Maka secara keseluruhan jumlah biaya tiap bulan yang harus dikeluarkan oleh produsen dengan mengunakan metode lama adalah sebagai berikut :

$\mathrm{PC}=\mathrm{Cm}+\mathrm{CI}$

Total = Rp.11.872.500,- + Rp.9.625.000,- = Rp. 21.497.500,-

b. Tahap Kreatif

Pada tahap ini, diperoleh beberapa alternatif dasar, yaitu:

1) SDM

Dalam sebuah usaha pengelasan peranan SDM sangatlah penting, jika SDM suatu usaha pengelasan unggul, maka perusahaan tersebut akan mendapatkan keuntungan lebih besar. Mulai dari keuntungan waktu hingga kualitas pengerjaan produk.

2) Bahan Baku.

Bahan baku adalah komponen terpenting dalam usaha pagar besi, karena menentukan hasil akhir dari produk tersebut.

c. Tahap Evaluasi

Pada tahap evaluasi ini, diperoleh informasi sebagai berikut:

1) SDM

Tabel 1. Untung-Rugi SDM dengan metode kerja VE

\begin{tabular}{|l|l|l|l|l|l|}
\hline No & Alternatif & \multicolumn{1}{|c|}{ Keuntungan } & Kerugian & \multicolumn{1}{c|}{ Biaya } & Hasil \\
\hline 1. & $\begin{array}{l}\text { Metode } \\
\text { kerja VE }\end{array}$ & $\begin{array}{l}\bullet \text { Proses produksi } \\
\text { cepat } \\
\begin{array}{l}\text { Pengerjaan rapi } \\
\text { Harga jual lebih } \\
\text { tinggi }\end{array}\end{array}$ & $\begin{array}{l}\text { Gaji } \\
\text { besar }\end{array}$ & $\begin{array}{l}\text { Rp. 50.000,-/hari } \\
\text { (tenaga } \\
\text { pengelasan) } \\
\text { Rp. 30.000,-/hari } \\
\text { (tenaga finshing) }\end{array}$ & $\begin{array}{l}4 \mathrm{~m}^{2} / \\
\text { hari }\end{array}$ \\
\hline
\end{tabular}

2) Biaya Tenaga Kerja (CI)

Jumlah tenaga kerja 5 orang, terdiri dari : 2 bagian Pengelasan, 3 bagian finishing

Pengelasan $=$ Rp.100.000,-/hari x 25 hari $=$ Rp.2.500.000,-

Finishing = Rp.90.000,-/hari $x 25$ hari= $=$ Rp.2.250.000,-

Konsumsi karyawan $=5 \times$ Rp. $7500 \times 25$ hari $=$ Rp.937.500,-

Total biaya tenaga kerja tiap bulan $=\mathrm{Rp} .5 .687 .500$,-

3) Bahan baku 
Bahan baku tidak berpengaruh pada proses penerapan rekayasa nilai, karena untuk menjaga kualitas produk, bahan baku tetap menggunakan bahan baku yang terbaik. Biaya Material $(\mathrm{Cm})$

Biaya material langsung yang harus dikeluarkan adalah sebagai berikut:

Besi 1 Rp. 60.000,-/lonjor $(6 \mathrm{~m}) \times 25$ lonjor/bulan = Rp. 1.500.000,-

Besi 2 Rp. 40.000,-/lonjor $(6 \mathrm{~m}) \times 234$ lonjor/bulan = Rp. 9.360.000,-

Cat 1 Rp.45.000,-/kaleng x 12,5 kaleng/bulan = Rp. 562.500,-

Cat 2 Rp. 20.000,-/kaleng x 10 kaleng/bulan = Rp. 200.000,-

Listrik = Rp.250,000,-

Total biaya material langsung tiap bulan = Rp.11.872.500,-

Jumlah produksi pagar tiap bulan : $100 \mathrm{~m} 2$.

Harga pagar tiap $\mathrm{m} 2$ : Rp. 450.000

Pendapatan kotor tiap bulan $=(100 \%-0,1 \%) \times 100 \times$ Rp. $450.000=$ Rp. 44.955 .000

Maka secara keseluruhan jumlah biaya tiap bulan yang harus dikeluarkan oleh produsen dengan mengunakan penerapan rekayasa nilai adalah sebagai berikut:

$\mathrm{PC}=\mathrm{Cm}+\mathrm{CI}$

Total = Rp.11.872.500,- + Rp.5.687.500,- = Rp. 17.560.000,-

d. Tahap Laporan

Tabel 2. Perbandingan Hasil Kerja Sesudah VE dan Sebelum VE dengan Pengurangan Jumlah Karyawan

\begin{tabular}{|c|c|c|c|}
\hline & & Sebelum VE & Sesudah VE \\
\hline 1 & Biaya Produksi & Rp. 21.497.500,- & Rp. 17.560.000,- \\
\hline 2 & Hasil Kerja & $\begin{array}{l}\text { - Menbutuhkan waktu } \\
\text { lama } \\
\text { - Hasil kurang } \\
\text { memuaskan } \\
\text { - Harga jual standart }\end{array}$ & $\begin{array}{l}\text { - Waktu pengerjaan } \\
\text { singkat } \\
\text { - Hasil memuaskan } \\
\text { - Harga jual meningkat }\end{array}$ \\
\hline
\end{tabular}

Tabel 3. Perbandingan Hasil Produksi Sesudah VE dan Sebelum VE

\begin{tabular}{|c|c|l|l|}
\hline No. & Nama Proses & \multicolumn{1}{|c|}{$\begin{array}{c}\text { Deskripsi Pekerjaan } \\
\text { Sebelum VE }\end{array}$} & \multicolumn{1}{|c|}{$\begin{array}{c}\text { Deskripsi Pekerjaan } \\
\text { Sesudah VE }\end{array}$} \\
\hline 1. & $\begin{array}{c}\text { Pemilihan } \\
\text { Bahan dan } \\
\text { Pemotongan } \\
\text { Bahan }\end{array}$ & $\begin{array}{l}\text { Sering terjadi kesalahan } \\
\text { dalam pemotongan bahan } \\
\text { baku, sehingga } \\
\text { membutuhkan waktu yang } \\
\text { lebih lama untuk proses } \\
\text { pengelasan }\end{array}$ & $\begin{array}{l}\text { Jarang terjadi bahkan } \\
\text { hampir tidak pernah ada } \\
\text { kesalahan pemotongan } \\
\text { bahan baku yang } \\
\text { menjadikan proses lebih } \\
\text { cepat }\end{array}$ \\
\hline 2. & Pengelasan & $\begin{array}{l}\text { Pengelasan sering kali } \\
\text { kurang rapi }\end{array}$ & Hasil pengelasan rapi \\
\hline 3. & Finishing & $\begin{array}{l}\text { Proses pengecatan masih } \\
\text { tradisional }\end{array}$ & $\begin{array}{l}\text { Proses pengecatan sudah } \\
\text { menggunakan peralatan } \\
\text { yang lebih moderen } \\
\text { (spray) }\end{array}$ \\
\hline
\end{tabular}

e. Tahap Implementasi

Meningkatkan kinerja usaha kecil menengah dengan pendekatan value engineering (M. M uslimin Ilham) 
Tahap yang terakhir dalam penerapan Rekayasa Nilai adalah tahap implementasi. Dengan mengetahui secara jelas dari hasil analisa maka pada tahap ini akan memberikan ketepatan bahwa Alternatif metode kerja VE dapat dikembangkan lebih lanjut pada UKM pagar besi Sumber Jaya, dan apabila dilaksanakan, maka akan memberikan keuntungan terhadap UKM pagar besi yang lebih besar.

\section{KESIMPULAN}

Penerapa metode Rekayasa Nilai (VE) dapat memberikan solusi yang lebih baik dalam rangka peningkatan kinerja perusahaan. Metode ini memberikan beberapa pilihan alternatif yang dapat dipilih oleh pemilik UKM. Metode kerja VE ini mempunyai keuntungan-keuntungan antara lain:

a. Proses produksi cepat

b. Pengerjaan rapi

c. Harga jual lebih tinggi

Sedangkan spesifikasi teknik yang dimiliki oleh alternatif metode kerja VE yang akan dijalankan adalah sebagai berikut :

a. Proses kerjanya tidak membutuhkan waktu lama untuk pembuatan 1 unit pagar besi minimalis. Untuk ukuran $8 \mathrm{~m} 2$ hanya dibutuhkan waktu 2 hari.

b. Mutu dan kwalitas yang disyaratkan mempunyai bentuk yang sempurna dan tidak cacat.

c. Sambungan bagian pengelasan tidak mudah patah oleh benturan / pukulan.

Pengurangan biaya dapat dilakukan pada metode Rekayasa Nilai. Perubahan metode baru pada proses produksi pembuatan pagar besi minimalis mempengaruhi pengurangan biaya-biaya tenaga kerja. Penguranagn biaya tersebut akan mempengaruhi naiknya peningkatan performance yang lebih tinggi dari produk. Sehingga nilai (VE) dari produk menjadi naik, akibatnya harga jual menjadi tinggi.

\section{DAFTAR PUSTAKA}

[1] Zimmerman, Larry W. and Hart, Glen D. 1982. Value engineering : a practical approach for owners, designers, and contractors. New York : Van Nostrand Reinhold, c

[2] SAVE Internationa. 2007. VALUE STANDARD nd BODY OF KNOWLEDGE. SAVE International Value Standard. http://www.value-eng.org/

[3] Moleong,Lexy. 1994. Metodologi Penelitian Kualitatif. Bandung:Remaja Rosdakarya

[4] Pasaribu, Muhammad Fazri dan Puspita, riana. 2016. Tahap Informasi, Kreatif, dan Analisa Pada Rekayasa Nilai Untuk Meningkatkan Kualitas Pelayanan Hotel. Industrial Engineering Journal Vol.5 No.2 (2016) 46-51.

[5] Abdul Chaer. 2007. Linguistik Umum. Jakarta: Rineka Cipta 